\title{
Proactive Therapy
}

National Cancer Institute

\section{Source}

National Cancer Institute. Proactive Therapy. NCI Thesaurus. Code C156230.

Therapy that is received or administered before a condition or symptom begins. 